\title{
Benchmarking Cost of Milk Production in 46 Countries
}

\author{
Torsten Hemme, Mohammad Mohi Uddin and Oghaiki Asaah Ndambi
}

\author{
IFCN Dairy Research Center at the University of Kiel, Kiel, Germany
}

\begin{abstract}
The global dairy industry is facing challenges due to the extremely volatile milk price and a substantial increase of feed prices. The goal of this study, therefore, was to compare and benchmark the cost of milk production in 46 countries representing $87 \%$ of the world's total milk production, using a standard method developed by the International Farm Comparison Network (IFCN). Two typical farms were selected per country; one average-sized and one larger farm. The cost of milk production in 2010 ranged from 16.91US-\$100kg Energy Corrected Milk (ECM) in Armenia to 97.27 US-\$100kg ECM in Switzerland, with cost differences mainly driven by the diversity in farming and feeding systems. Based on costs, world regions were categorized into four levels: 40-50 US-\$ in the EU, Middle East and China; 30-40 US-\$ in the USA, Brazil, CEEC and Oceania; <30 US- $\$$ in Africa, Asia, South America; $>60$ US- $\$$ in Austria, Norway, Switzerland and Canada. The major drivers for this variation were ranked as; purchased feed cost (the highest) followed by labor, land and machinery costs. Regression analyzes showed that costs were highly correlated milk yield and milk price but not to herd size.
\end{abstract}

Keywords: Benchmark, cost of milk production, International Farm Comparison Network, typical farm.

\section{INTRODUCTION}

In recent decades, and mostly in industrial countries, there has been a structural change in dairy farming systems towards an increase in herd size but a decrease in the number of farms (Breustedt and Glauben, 2007) while, on the other hand, there has been an increasing tendency toward intensification of dairy farming in both developed and developing countries (Alvarez et al., 2008). These structural changes, together with the globalization of the economy and the on-going liberalization of agricultural trade policy, may lead to a considerable re-allocation of agricultural production worldwide (Isermeyer et al., 2003). This may result to an increase in factor and input prices for agricultural production particularly dairy enterprises. On the other hand, the key output price, in this case the milk price, is very volatile and does not always increase as fast as the input prices. Moreover, the quota abolishment in Europe by 2015 will promote structural changes in dairy farming systems, triggering greater production and a more competitive milk market.

Thus, the dairy industry worldwide has been facing tremendous challenges in order to stay in business in such a changing and dynamic dairy market. The dairy stakeholders, therefore, should make investments in updated information so as to be aware of the current and future state of the dairy industry. Among the stakeholders of the world dairy chain, farmers have the greatest share of costs and are therefore the key target for cost reduction.

*Address correspondence to this author at the IFCN Dairy Research Center at the University of Kiel, Schauenburger Str. 116, D-24118 Kiel, Germany;

Tel: +49 4315606 251; Fax: +49 4315606 262;

E-mails: torsten.hemme@ifcndairy.org,ndamboa@yahoo.com
Cost of milk production especially the estimation of cash and economic costs is the key indicator for sustainable dairy farming (Van Chalker, 2005) as well as the means of measuring overall economic competitiveness both factor and product market, locally and internationally (Thorne, 2004). Therefore, to remain competitive, dairy organizations and farmers must strive to reduce costs at farm level (Koonawootrittriron et al., 2012).

Furthermore, the cost is associated with profit and the higher profitability is associated with less likelihood of leaving dairying (Brag and Dalton, 2004). The importance of using farm costs and calculation for policy formulation is also increasing over time, as the policy makers can decide to what extent the farmers should be supported. In this regards, the cost calculation is considered a "help tool" that supports the decision-making process on future investment on the farms, develops strategies within and among the competitors nationally and internationally, and thus facilitates the evaluation of the competitiveness of the dairy sector.

Based on this background, analysis of cost might play an important role in both econometric and biological simulation models. However, the analysis of cost from theory of competitiveness imposes significant challenges in benchmarking the world dairy farms. The key challenges faced in estimating costs are:

i) Changing economies of scope

ii) Technological change which is dynamic in nature

iii) More than one dimension in single cost items 
iv) Existence of several unmeasured/unobservable costs (e.g. hedonic costs, shadow costs, opportunity costs etc.)

v) Despite a high level of specialization in management, it is difficult to allocate all the cost items due to the multi-functional and/or integrated nature of the farms. First, the farm level costs must be ascertained, and later on shared among the enterprises or recalculated using different estimation norms

vi) The limited availability of comparable global data sets to fulfill specification of the econometric models makes it necessary to develop a method that can estimate costs from data sets obtained from diverse farming systems and compare them internationally

The International Farm Comparison Network (IFCN) method was developed based on the typical farm approach (TFA) and is able to handle those limitations and challenges. The application of TFA in typical farm selection, data collection and validation has a strong scientific basis due to its ability to produce results with minimal resources (Ndambi and Hemme, 2009; Uddin et al., 2010, Uddin et al., 2012; Hagemann et al., 2011). In addition, the IFCN databases cover all major world trading regions and apply a common methodology for costs identification and calculation (Isermeyer, 2012). Considering the importance of cost estimation for understanding global competitiveness of the dairy industry and taking into account the methodological challenges on global cost comparison, this study has envisaged the following research questions:

How much does it cost to produce milk in different parts of the world? and
How can we measure and compare the cost of milk production in diverse farming systems in an unbiased manner?

To answer this research question the following two objectives were undertaken in our study:

i) Compare and benchmark the farm level cost in global milk production in 46 countries by applying the IFCN method.

ii) Identify the underlying drivers for of the cost of milk production worldwide in order to find strategies for reducing cost and improving competitiveness in the global dairy industry

\section{LITERATURE REVIEW ON COST ESTIMATION METHOD}

Several concepts have been applied to the definition of cost of production and cost estimation methods (FACEPA, 2008). The cost is defined as the value of the production factors consumed or used to reach a final goal. Although every farm has its own cost structure (depending on the main activity or enterprises), it is possible to identify some typical cost classes which are depicted in Table 1.

In the same way as with cost concepts, there are also several methods which are found in the literature to calculate and estimate cost of production. There are three main approaches: i) Descriptive analysis approach; ii) Statistical analysis approach (survey approach); and iii) Economic-engineering approach (French 1992). Each of them has certain advantages and limitations but in general they provide the basis to combine one or more methods into one single calculation model for full cost estimation. However, still the combined model is more a theoretical than a practical implication and faces several challenges. These challenges arise due to: first, there being no

Table 1: Classification of Cost Concepts and its Explanations

\begin{tabular}{|l|l|l|}
\hline Classification Principles & Type & Explanations \\
\hline \hline $\begin{array}{l}\text { Relation and reference to the } \\
\text { final project }\end{array}$ & $\begin{array}{l}\text { Traceable cost; Common cost; } \\
\text { Direct cost; Indirect cost }\end{array}$ & $\begin{array}{l}\text { Direct costs are traceable while indirect costs can be either } \\
\text { traceable or common. Common costs are indirect. }\end{array}$ \\
\hline Behaviour & $\begin{array}{l}\text { Variable cost; Fixed cost } \\
\text { Quasi-fixed cost }\end{array}$ & $\begin{array}{l}\text { Variable costs are traceable and direct. Fixed cost can be traceable } \\
\text { and common. The fixed costs are "fixed" in the short-term. }\end{array}$ \\
\hline Monetary transaction & Explicit cost; implicit cost & Implicit cost is an opportunity cost \\
\hline Time period & $\begin{array}{l}\text { Short-term cost; Medium-term } \\
\text { cost; Long-term cost }\end{array}$ & Long-term cost takes into account the opportunity cost \\
\hline
\end{tabular}

Source: Adapted from FACEPA, 2008. 
Table 2: Development of an International Cost Comparison Method for Milk Production Worldwide

\begin{tabular}{|c|c|c|c|c|c|c|}
\hline Authors & Country & Approach & Data Basis & Method & $\begin{array}{l}\text { Year of } \\
\text { Analysis }\end{array}$ & $\begin{array}{c}\text { Publication } \\
\text { Year }\end{array}$ \\
\hline Isermeyer (1989) & $\begin{array}{l}\text { EU-12, USA, } \\
\text { Canada, New } \\
\text { Zealand }\end{array}$ & Farm notes & $\begin{array}{l}\text { Book keeping; } \\
\text { FADN (Farm } \\
\text { Accountancy Data } \\
\text { Network); ERS } \\
\text { (Economic } \\
\text { Research Service) }\end{array}$ & Full cost & 1983 & 1989 \\
\hline Fingleton 1995 & $\begin{array}{l}8 \text { Countries: } \\
\text { DE, BE, } \\
\text { DK,FR, UK, } \\
\text { IT,IE; NL }\end{array}$ & $\begin{array}{l}\text { Interpretation of Farm } \\
\text { Records/Farm Notes }\end{array}$ & $\begin{array}{l}\text { Book keeping, } \\
\text { FADN }\end{array}$ & Full cost & $\begin{array}{c}1990- \\
1993\end{array}$ & 1995 \\
\hline $\begin{array}{c}\text { Richardson et al., } \\
\text { (1996) } \\
\text { Knutson et al., (1997) } \\
\text { Miller (1997) }\end{array}$ & $\begin{array}{l}3 \text { Countries: } \\
\text { US; MX; CA }\end{array}$ & $\begin{array}{l}\text { Engineering approach, } \\
\text { Survivor technique }\end{array}$ & $\begin{array}{l}\text { Panel approach; } \\
\text { Typical farm }\end{array}$ & $\begin{array}{l}\text { Cash cost; } \\
\text { FLIPSIM Model }\end{array}$ & 1996 & 1996 \\
\hline $\begin{array}{c}\text { Wageningen } \\
\text { Economic Papers }\end{array}$ & $\begin{array}{l}\text { The } \\
\text { Netherlands }\end{array}$ & Farm notes & $\begin{array}{l}\text { FADN for sandy } \\
\text { soils }\end{array}$ & Family farm income & $\begin{array}{l}1989- \\
1993 \\
\end{array}$ & 1996 \\
\hline Hemme, 1996 & $\begin{array}{l}12 \text { Countries: } \\
\text { DE; FR; DK; } \\
\text { NL; UK; IE; } \\
\text { HR; PL; AR; } \\
\text { US; AU; NZ }\end{array}$ & $\begin{array}{l}\text { Panel Approach; } \\
\text { Typical farm; } \\
\text { Farm note?? }\end{array}$ & Book keeping & $\begin{array}{l}\text { EDF Method, Full } \\
\text { cost with allocation } \\
\text { factors }\end{array}$ & $\begin{array}{l}1995- \\
1996\end{array}$ & 1996 \\
\hline $\begin{array}{c}\text { The Economic } \\
\text { Research Service }\end{array}$ & $\begin{array}{l}\text { USA and } \\
\text { Regional }\end{array}$ & $\begin{array}{l}\text { Survivor technique; } \\
\text { every 3-8 farms } \\
\text { updated }\end{array}$ & $\begin{array}{l}\text { Statistics; } \\
\text { bookkeeping; } \\
\text { estimations }\end{array}$ & $\begin{array}{l}\text { Full cost; updated } \\
\text { each year (price, } \\
\text { acreage, production } \\
\text { changes) }\end{array}$ & $\begin{array}{l}\text { Since } \\
1979\end{array}$ & Every year \\
\hline $\begin{array}{l}\text { European dairy } \\
\text { farmers }\end{array}$ & EU & Farm notes & $\begin{array}{l}\text { Book keeping; } \\
\text { questioning of } \\
\text { farmers }\end{array}$ & Full cost & $\begin{array}{l}\text { Since } \\
1995\end{array}$ & Every year \\
\hline Hemme et al., 2011 & $\begin{array}{l}49 \text { Countries } \\
\text { from all six } \\
\text { continents }\end{array}$ & Typical farm approach & $\begin{array}{l}\text { IFCN farm level } \\
\text { data base }\end{array}$ & $\begin{array}{l}\text { Full cost; Dairy } \\
\text { enterprise cost: } \\
\text { activity base cost; } \\
\text { allocation cost; } \\
\text { Simulation etc. } \\
\text { TIPI-CAL model }\end{array}$ & $\begin{array}{l}\text { Since } \\
2000\end{array}$ & $\begin{array}{l}\text { Every year } \\
\text { as "Dairy } \\
\text { Report" }\end{array}$ \\
\hline
\end{tabular}

Source: Updated after Hemme (2000).

$\mathrm{AR}=$ Argentina, $\mathrm{AU}=$ Australia, $\mathrm{BE}=$ Belgium, $\mathrm{CA}=$ Canada, $\mathrm{DE}=$ Germany, $\mathrm{DK}=$ Denmark, FR= France $, \mathrm{IE}=\mathrm{Ireland}, \mathrm{MX}=\mathrm{Mexico}, \mathrm{NL}=\mathrm{The}$ Hetherlands, NZ = New Zealand, PL= Poland.

method to collect compatible farm level data sets from all over the world, and secondly, the fact that the application of a survey technique to collect individual farm level data is too expensive in terms of cost, time and resources.
Several efforts have been made to overcome uncertainties and challenges in global data collection and cross-country cost comparison, (see Table 2) (Richardson 1996; Hemme, 2000; Ndambi and Hemme 2009; Uddin et al. 2010; Isermeyer 2012). Until the late 
1980s, international farm comparisons were only carried out on an ad hocbasis, mainly within the scope of Ph.D studies (Isermeyer 1989; Deblitz 1994; Hemme 2000). The results of these comparisons were recognized as being useful. At the same time they revealed the following problems (Isermeyer et al. 2003):

- $\quad$ required data was either not available at all or not available in the scope required to perform total cost analysis

- available data did not allow costs to be differentiated into their price and their volume components to explain drivers for cost differences

- available data was usually not comparable across countries

- $\quad$ available data was very often outdated

- the organizational framework of the studies was not designed to be sustainable

The main conclusion from these experiences was that it would be more efficient to establish a new database for international farm-level comparisons than to adjust existing databases. As a consequence, in 1991, the network of the European Dairy Farmers (EDF) was founded to explore the feasibility of ongoing farm comparisons in the European dairy sector. EDF is a club of individual dairy farms, the data of which are analyzed on an annual basis. Despite solving the above-mentioned problems, a number of challenges remained:

- The possibility for generalizing results was limited because individual farm data were used

- The analysis was limited to Europe only

- Data collection and cost allocation and results were not validated by experts

- There was no possibility for simulating farm results/costs into the future

Despite efforts from the international community as shown in Table 2, the real problems were not solved. A growing need became manifest for the development of a compatible and sustainable method that could be used to compare farms worldwide (FACEPA 2008). However, in 2012, an attempt was made on international cost comparison in agriculture by using national survey in EU and several other countries but end up with recommendation that there might need a common approach for data collection and analysis globally (Isermeyer et al., 2012) which again showed the need for the application of IFCN method. This fact impelled the International Farm Comparison Network (IFCN) to use a network idea and develop a method which was more holistic in nature and had the capacity to include as many cost items in the cost analysis as possible. Consequently, IFCN was founded in 1997 creating a new method with the possibility of overcoming the above-mentioned problems (Hemme, 2000), and has been strengthened by a growing number of countries in the analysis and an annual data collection and validation process leading to better outputs every year.

\section{MATERIALS AND METHODS}

Estimation of production costs is a complex process encompassing issues spanning from data collection design to selection and development of methodologies for processing and analysis. The IFCN method is based on three key pillars: i) the Network approach ii) Technology Impact Policy Impact Calculation (TIPICAL) model and iii) Typical Farm Approach (TFA). The application of this method helped to overcome the shortcoming of the traditional cost analysis mentioned above because it has the capacity to make input use and cost parameters comparable. In this way very diverse farms can be used to build typical farms making it possible to benchmark the cost for all typical farms worldwide.

\section{Typical Farm Approach (TFA)}

The key issue in creating high quality farm comparison results worldwide is to apply the same method to all farms. Therefore this method used the Standard Operating Procedure, called "Typical farm approach" (TFA). The inception of using typical farms or representative farms in economic analysis occurred in 1928 when Elliot defined a typical farm as being "a modal farm in a frequency distribution of farms of the same universe; or it is representative of what a group of farmers are doing who are doing essentially the same thing"(Dillon and Skold 1992, AFPC 2010). In IFCN, a typical farm represents a certain production system, farm size, production technology used and the related milk volume in a country/dairy region. The technical and economic data to describe the typical farms are preferably neither individual farm data nor statistical averages but based on a consensus 
achieved in a panel meeting. Two typical farms are set up in each region. First farm: Mode sized farm with average management performance (mode is the value that occurs most frequently). Second farm: This farm is selected from the second most common farming system having larger herd sizes than the first one. Its purpose is to give an idea on the economies of scale and/or future potential of dairy farming in the region. Both farm types should also have an average management performance within the selected system. The TFA has advantages over other available methods e.g. FADN (Farm accountancy and data network), USDA (United States Department of Agriculture) and the survey method, because TFA focuses more on local knowledge in the selection of dairy regions and in defining typical farms with key variables, which are later validated by local experts. In addition, the data obtained from typical farms represent real farming rather than statistical farming (Dillon and Skold 1992).

\section{i) Selection of Typical Farms, Data Collection and Validation}

Applying the TFA approach, 104 typical farms (one average sized farm and one larger-farm size) from 46 countries and 52 dairy regions were selected for this study. This approach is able to evaluate the heterogeneity of farm structure, diversity of the production system, and size of the country thus making them comparable on a global scale. The selection of countries and typical farms was based on the volume of milk production, data availability, data quality and geographical coverage. The selected countries represented $87 \%$ of the world's total milk production (Figure 1).

The detailed description of the typical farms selected for this study is presented in Annex A1 and A2.

After selecting typical farms, the data pertaining to this study was collected by using the Panel Approach ${ }^{1}$. The quality of the data was ensured through the development of standard tools for cross comparison and validation data and results.

${ }^{1}$ IFCN Panel Approach consists of successive meetings of 3-5 farmers, 1 national expert, 1 regional expert, 1 representative from the ministry of livestock and 1 external researcher. The objective is to obtain more reliable farm level data with a validation process with farmers, experts and researchers in the respective regions and production systems. The IFCN panel approach is similar to a modified Delphi technique (Custer et al. 1999). However, the application of TFA and panel approach is considered scientific, produces fast and in-depth results and requires minimal resources and costs.

\section{ii) Validation of the Data}

The next step after the data collection is to analyze and validate results. This is a very important step of the TFA on which we have begun to focus more since 2010. After including the data into the TIPICAL model, a cross check of the results is vital as an initial step to the data validation process. This was done in one of the following ways: a) a review with accounting statistics, b) a review with the same panel of farmers who were involved in collecting the data, c) a review with national experts, d) own review of results by country partner and e) other review methods adapted to the country situation.

\section{IFCN Network Approach}

The IFCN is a global knowledge-creating network in milk production that connects different stakeholders (dairy farmers, researchers, dairy related companies, investors, policy makers, advisors and dairy institutions) in the global milk supply chain. The network concept is the unique characteristic of the IFCN method and it makes the IFCN method advantageous over others. The role of the network is to ensure the formal relationship among the researchers and other dairy stakeholders that assures their commitment to deliver and validate typical farm data annually. In addition, country specific research project has been done to improve the method and model each year which is extra-ordinarily beneficial for ensuring high quality data and updating cost comparison results.

\section{TIPICAL Model}

This model first of all standardizes input variable to enable their comparability across countries and then calculates various outputs.

\section{Standardization of Input Data and Estimation of Cost}

The estimation of cost of milk production in the TIPICAL model of IFCN method (Hemme, 2000) is described as $f(c)=f(x, w)$ where, $c=$ is the cost, $x=$ the level of inputs, and $w=$ prices for inputs. This TIPICAL model is based on the principle of classical cost functions. An additional adjustment in the model was made to include factors that are not directly considered as physical inputs but affect the costs, for example, quota costs and opportunity costs for owned factors of production. The model runs through a number of indicators stepwise in order to estimate the costs. Two cost parameters were estimated in the model: 


\section{Milk production in mill tons ECM (4\% fat, $3,3 \%$ protein)} cows, buffalo

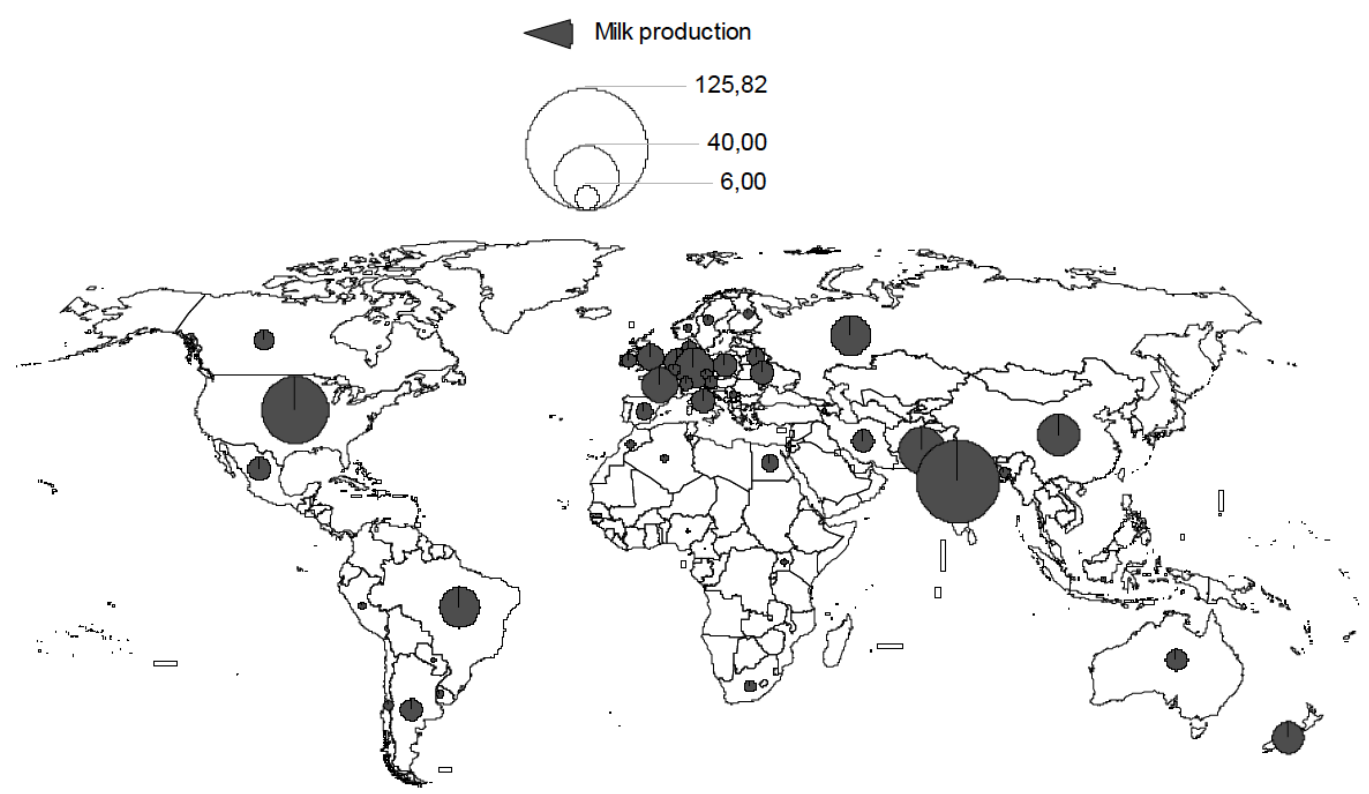

Figure 1: Milk production (million ton) from cows and buffaloes in the analyzed country $(n=46)$.

- Total cost of the dairy enterprise which takes into account all costs for producing milk, replacement calves and heifers, and all other outputs of the dairy enterprise. These include cash costs, opportunity costs for production factors and depreciation for buildings and machinery.

- $\quad$ Cost of milk production only, which is based on the Profit and Loss accounts (P\&L) e.g. cash costs, depreciation of factors of production and opportunity costs for farm owned factors (family labor, own land and capital) and quota costs.

In this study, the inputs (expressed as per $100 \mathrm{~kg}$ ECM) used to calculate the total cost of the dairy enterprise were: animal purchases, feed, machinery (maintenance, depreciation, contractor), fuel, energy, lubricants, water, buildings (maintenance, depreciation), veterinary and medicine, insemination, insurance \& taxes, other inputs dairy enterprise (quota); VAT balance (if negative). The cost of factors was also expressed per $100 \mathrm{~kg} \mathrm{ECM}$ and entered into the model, as: $\mathrm{w} 1=$ total land, $\mathrm{w} 2=$ capital and $\mathrm{w} 3=$ labor costs.

The second key variable calculated in this analysis is the cost of milk production only.

The 'cost of milk production only' refers to the cost related only to milk production. The estimation is modeled on the Profit and Loss (P\&L) account. The cost is derived by subtracting the expenses for nonmilk returns from the $P \& L$ account. The $P \& L$ account is related to the total returns of the dairy enterprise including milk and non-milk returns (cattle returns and coupled direct payments). To indicate the effect of opportunity costs, they are shown separately from the other costs (see Figure 2). This method of estimating cost of milk production only makes the method unique and more powerful in comparing cost on a global scale, because all the cost associated to beef, heifers and other non-milk related costs is adjusted so that it is applicable all over the world.

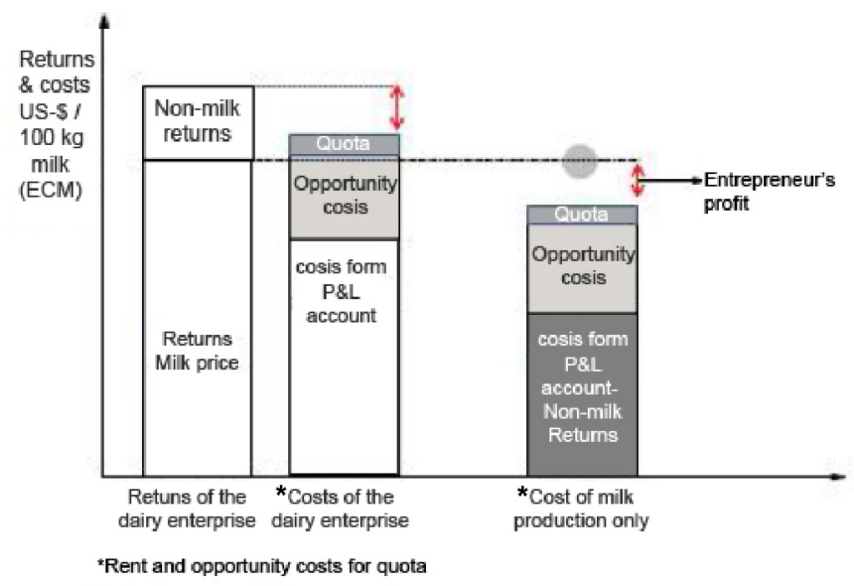

Figure 2: Cost of milk production only.

Thus, the model calculates Cost of milk production only, as shown below: 
$\mathrm{C}_{\text {milk }}=\sum \mathrm{P} \& \mathrm{~L}$ account $-\sum \mathrm{Nmr}$

Where, $\mathrm{C}_{\text {milk }}$ is the cost of milk production only, P\&L is the profit and loss account taking into account all of the cash and non-cash cost and quota, Nmr is the nonmilk returns (as is seen also in Figure 2).

However, for estimations and calculations of opportunity costs, the following assumptions were made:

Labor costs: Cash labor cost currently incurred was used for hired labor and the average wage rate per hour in the region was used for unpaid family labor.

Land costs: Rents currently paid by the farmers. Regional rent prices provided by the farmers were used for owned land.

Capital costs: Own capital was defined as assets, without land, plus circulating capital. For borrowed funds, a real interest rate of 6 percent was used; for owner's capital, the real interest was assumed to be 3 percent (Isermeyer 1998).

Depreciation: Machinery and buildings were depreciated using a straight-line schedule on purchase prices with a residual value of zero.

Adjustment of VAT: All cost components and returns are stated without value added tax (VAT).

Adjustment of milk to ECM: The milk output per farm was adjusted to ECM with $4 \%$ fat and $3.3 \%$ protein. ECM was obtained using the formula: ECM = Milk production / $\left(\left(0.383^{*}\right.\right.$ fat $\%+0.242$ * protein $\%+$ 0.7832)/3.1138) (IDF 2003).

The difference between two cost estimation methods: i) total cost of the dairy enterprise and ii) cost of milk production only, lies in the fact that the first one shows the total cost of the dairy enterprise considering the whole farm approach, while the second one takes into account the cost of milk production only. Total cost includes all of the cost items related to producing milk, raising heifers and calves. On the other hand, cost of milk production only includes all the costs allocated specifically to milk production. Since the costs for raising heifers and calves are difficult to estimate, in our method, an assumption was made that the returns from heifers, and calves equal to their cost, thus we subtracted these returns from the total cost, to derive cost of milk production only. The returns from other components of the dairy enterprise except milk were called "non-milk returns (NMR)". This approach helps to standardize the IFCN method in order to benchmark all the dairy farms globally, independently from the farm type, whether it is a specialized dairy (100\% dairy), a dual purpose (dairy and beef) or mixed farming (mostly in developing countries). Hence, in this study, we used cost of milk production only as a cost indicator to benchmark the farms in order to apply the same method to all farms worldwide.

\section{Defining Result Variables}

Farm size and milk yield. The farm size represents the average number of adult dairy cows (dry and lactating) per farm over a calendar year. More detailed information on all farms analyzed in this study is also listed in Appendix A1 and A2. On the other hand, the milk yield is expressed according to ECM. Based on farm size, the study analyzed two typical farms, an average-sized typical farm and a larger-typical farm from each dairy region and country with a few exceptions (e.g. Germany, France, and Egypt) in order to bring more regions due to very diverse production systems.

Total Costs of Dairy Enterprise. The total cost of milk production was used in this study to show the actual farm level costs considering the whole farm approach.

Non-milk returns. This includes returns from sales mainly from beef calves, culled cows and sometimes from other sources such as manure or surplus feed. Direct payments may be a substantial part of farm income; meanwhile, other subsidies (fuel, fertilizer, insemination, etc.) are also important in some countries. This variable was used to analyze the return structure and provide a general idea of the best regions for milk sourcing. At the same time, this was also used as an indicator of farm expenses on non-dairy cattle (e.g. beef cattle, breeding bulls, cull cows, manure) which, once subtracted from the P\&L account, will generate cost per unit on dairy enterprise.

Cost of milk production only. This represents only the cost of producing milk on the farm, excluding all other activities within the dairy enterprise. Unlike the total costs of the dairy enterprise which includes all costs for producing all dairy outputs (milk, cattle, manure, etc.), the cost of milk production only is the cost associated to production of a single output (milk). In other words, the cost of milk production only is the part of the total cost of the dairy enterprise which is attributed to the production of milk alone. 


\section{RESULTS AND DISCUSSION}

\section{Description of the Farms Analyzed: Farm Size and Milk Yield}

The farm size (number of cows per farm) and milk yield (1000 kg ECM/cow/year) are depicted in Figures 3 and 4 , respectively. The mean typical farm size of the analyzed countries was 203 cows per farm with a very wide range from 2 to 2443. The analysis on geographical distribution revealed that the highest average farm size was found in Oceania (480 cows/farm) followed by (Central and Eastern European Countries (CEEC) and Middle-East (430 cows/farm), North America (352 cows/farm), South America (146 cows/farm), Africa (117 cows/farm), Western Europe (WE) (110 cows/farm) and Asia (42 cows/farm). The continuous consolidation process for dairy farming in USA makes the farm size larger, while the predominance of small-scale farms in Asia results in the lowest farm size.

The greatest variation in cost was observed in the case of CEEC countries, such as Serbia, Belarus and Russia, due to the fact that these countries have dual farming systems, either very large corporate farms (farm size $>2000$ e.g. RU-2443) or small farms (e.g. RS-2). This was mainly driven by the government's agricultural policy. Until 1990, the agricultural policy of Eastern European countries aimed at developing large farms. After 1990 different trends were observed: a) large farms were maintained (Belarus, the Czech Republic), b) large scale farms were reorganized and the cows distributed to smaller household farms (Ukraine), and c) the family farm culture became stronger in Poland where $95 \%$ of Polish dairy farms keep less than 20 cows. A similar situation was observed in Russia, where, due to the availability of cheap land, larger farms have been established. The opposite could be seen in Norway, Switzerland, Finland and Austria where geographical conditions and land tenure systems hinder the development of larger farms.

The typical farm size, however, was a close approximation to the national statistical farm size in Western Europe, Africa, Asia and Australia. The exceptions were, once more, observed in some of the central and eastern European countries (CEEC) e.g. BY and RU, eastern Germany, IT, UK, SE and South Africa. Only Australia and New Zealand showed a statistical average of more than 200 cows per dairy farm. The large herd size was favored by the availability of high quality pasture and a suitable climate. The farms usually don't have price support for milk and are therefore forced to find ways of ensuring that their cost of production is lower than the world market price for milk. Considering that about $85 \%$ of costs are fixed on pasture based farms, the strategy of increasing farm size enabled farms to lower the costs of production, while at the same time, delivering an improved net return to the family. In addition, the presence of a liquid land market facilitated the trade of farms, making it easier for farms to merge.

In a similar way (to farm size), milk yield varied substantially from 722 (e.g. Bangladeshi 2 cow small

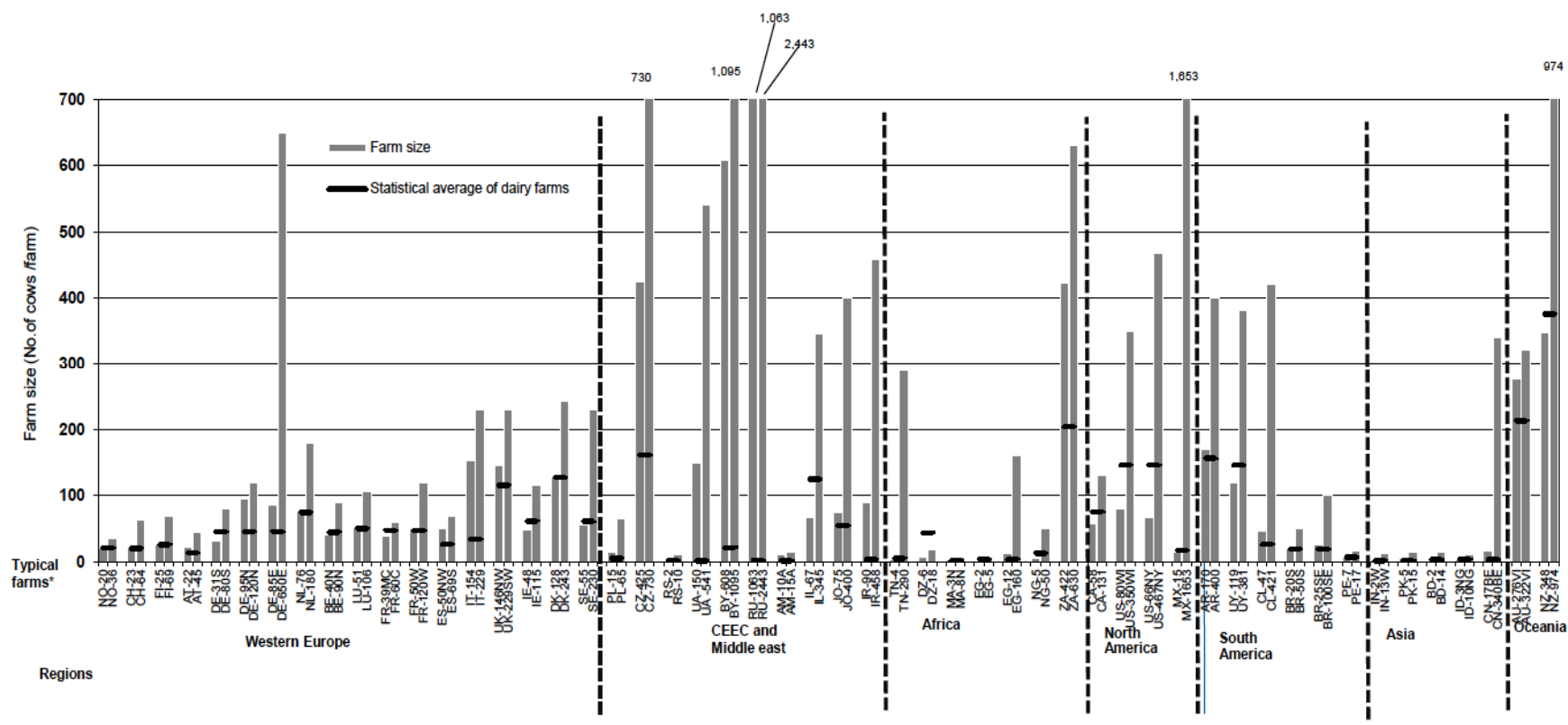

Figure 3: Farm size (no. of cows/farm). 


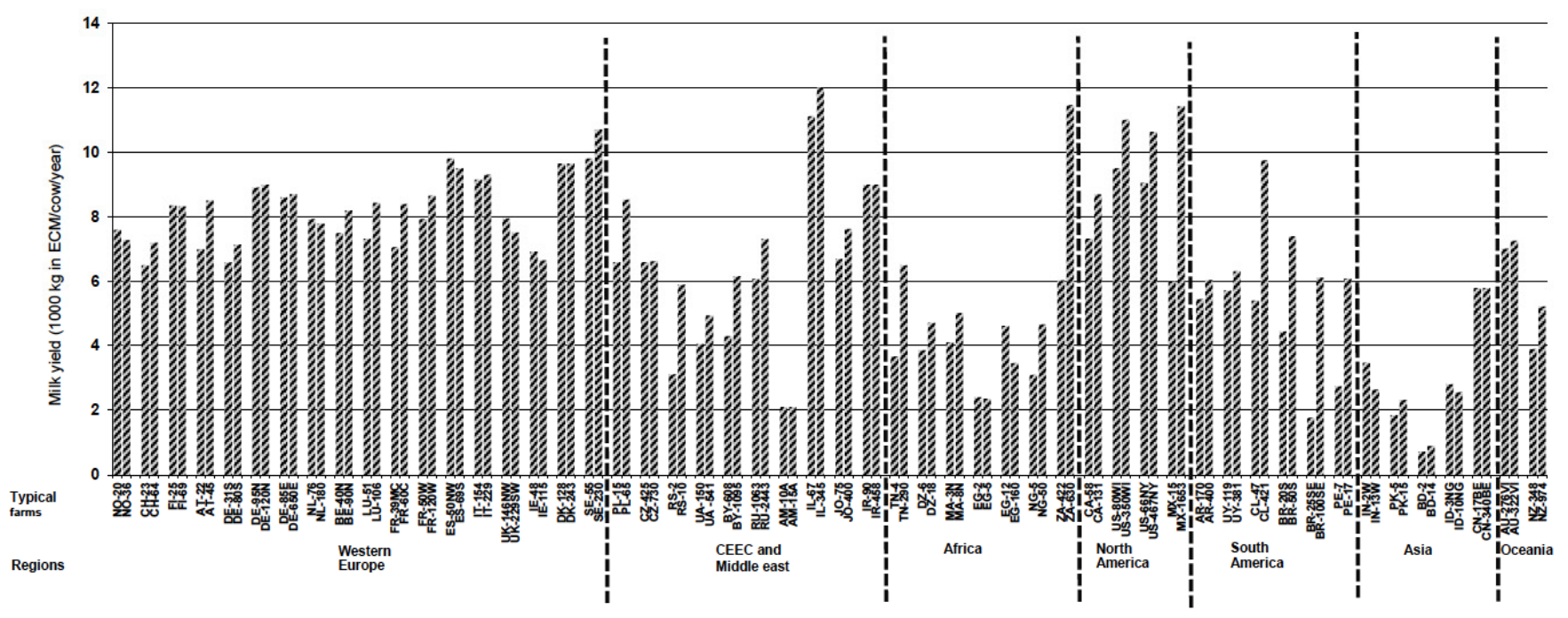

Figure 4: Milk yield (1,000 kg ECM) in typical farms analysed.

farm) to $11993 \mathrm{~kg}$ ECM per cow per year (e.g. Israel 345 cow large farm). The lowest in 2010 milk yield was observed in Asia (2834 kg ECM/cow/year). The main reasons were that most of the farms in Asia are small household farms with a low input and output system. Oceania had the highest average farm size but a moderate milk yield (6139 kg ECM/cow/year). On the other hand, the highest average milk yield was observed in North America (8864 kg ECM per cow per year). Based on milk yield, the farms were assembled in three groups: High, moderate and low milk yield producing countries. The results showed that farms having Holstein Friesian cows with intensive management and feeding systems had a milk yield of more than $7,000 \mathrm{~kg}$, up to $12,000 \mathrm{~kg}$. This was the case in Western Europe, USA, and Israel. Generally, about $60 \%$ of all farms analyzed were pure Holstein Friesian farms. Moderate milk yield was observed mainly in grazing based farms with less intensive feeding and/or management, as well as farms with other breeds, (not Holstein Friesian) such as dual purpose breeds. These farms, found mainly in the CEEC, Latin America, China and Oceania, generally had a milk yield of 4,000 to $7,000 \mathrm{~kg}$. Meanwhile, Low milk yield was considered to be farms producing less than $4000 \mathrm{~kg}$. These were mainly found in Africa, South and South East Asia and other countries which had buffaloes, local breeds, and crossbreeds with a high share of local genetic composition. The conversion of natural fat content to ECM favored buffalo farms in Egypt and Pakistan, as well as the farms in Finland, Ireland, Luxembourg and New Zealand, due to higher fat and protein content ( $>4 \%$ and $>3.3 \%$ respectively). On the other hand, most farms in the Middle East, North America and Latin America had a lower fat and protein content, giving them a disadvantage in milk yield due to the ECM conversion.

\section{Cost of Milk Production Worldwide}

\section{i) Total Costs of Dairy Enterprise}

The total costs of milk production analyzed in this study are depicted in Figure 5. The mean total costs for the dairy enterprise was 53 US-\$/100 kg ECM with a standard deviation of 21.54 US- $\$ / 100 \mathrm{~kg}$ ECM. The highest average total costs of a dairy enterprise was found in Switzerland (156.87 US-\$/100 kg ECM) while the lowest average cost was observed in Uruguay's 119 cow farm (24.44 US-\$/100 kg ECM)). Among different components, the purchased feed costs comprised the highest cost item in the total cost of milk production ranging from 3.96 to $50.60 \mathrm{US}-\$ / 100 \mathrm{~kg}$ ECM with an average cost of feed of about 18.41 US$\$ / 100 \mathrm{~kg}$ ECM.

Based on the average value, the next highest cost item was labor (11.27 US-\$/100 kg ECM) followed by depreciation of machinery (4.75 US-\$/100 kg ECM). The farms from Middle-east (Jordan, Israel, and Iran), Africa (except large farms in Morocco) and China had a relatively high proportion of feed costs on total costs. The highest proportion of feed cost on total costs was observed for the Iranian farm (IR-90) (84\%) while in the farm from Jordan (JO-400) it was approximately $79 \%$. The main reason for this was that they are located on deserts, there is very little rainfall and therefore it is not possible to produce any feeds. Feed was mainly imported from abroad thus increasing their feed cost. The same was observed in the case of China, where the farms were feedlots due to lack of arable 


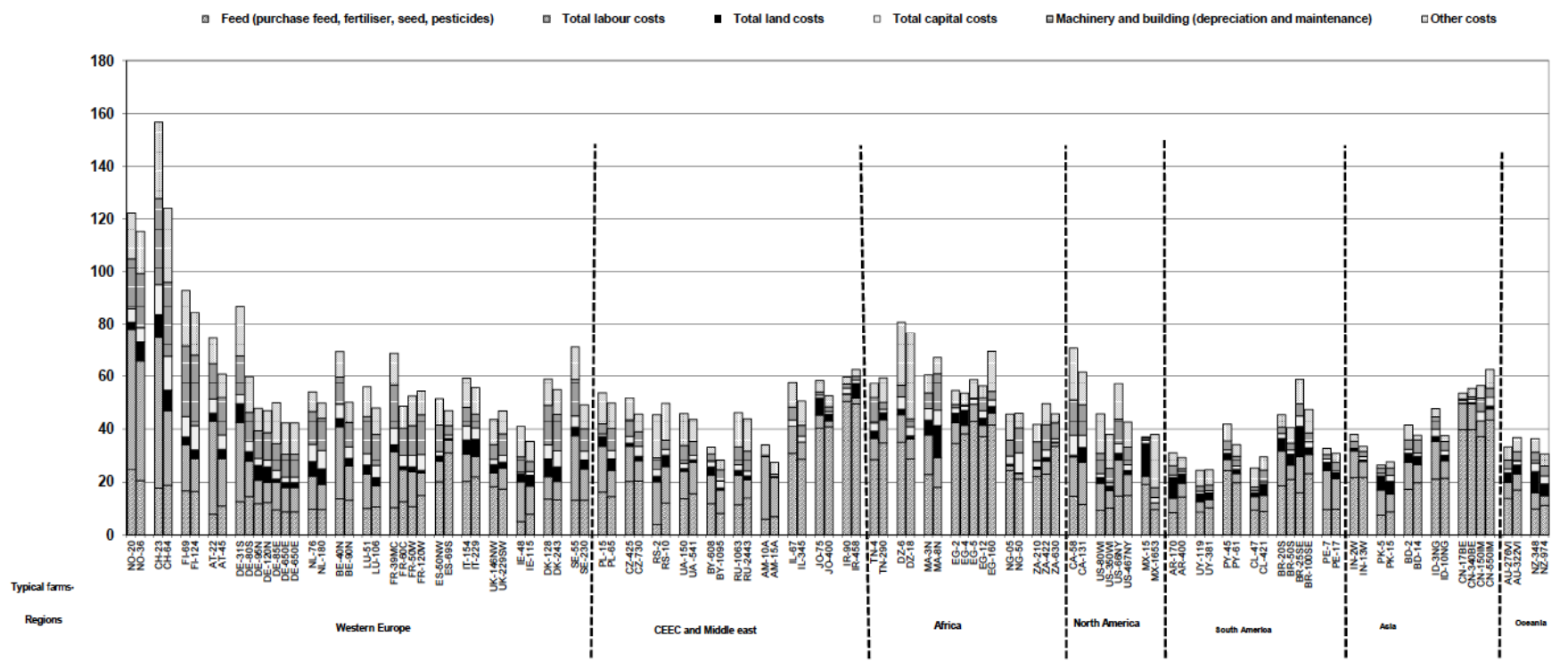

Figure 5: Total costs of milk production (US- $\$ 100 \mathrm{~kg} \mathrm{ECM)} \mathrm{in} 46$ countries.

landleading to a greater use of purchased feeds. In terms of labor costs, Norway, Switzerland and Austria showed relatively higher laborcosts as wages are substantially higher in these countries.

\section{Non-Milk Returns (NMR)}

The non-milk returns of different farms are depicted in Figure 6. It is evident that some countries, especially Western Europe (NO, CH, FI, AT), and almost all the African and Asian countries (except South Africa, India and Pakistan) had, in general, high NMR. The highest NMR was found in the $\mathrm{CH}-23$ farm (59.60 US- $\$ 100 \mathrm{~kg}$ ECM) while the lowest was in PK-5 (1.3 US- $\$ 100 \mathrm{~kg}$ ECM). This implied that farms with lower milk yield had higher non-milk returns, since these returns were expressed per $100 \mathrm{~kg}$ of milk (Africa, Asia). When including subsidies, mainly direct payments, the highest NMR were observed in farms from Switzerland $(\mathrm{CH}-23)$, Norway (NO-20) and Algeria ((DZ-6). This indicated that direct support to the dairy farmers played a key role in determining the NMR. On the other hand, the highest average NMR was evidently higher in Africa, mainly from cattle returns, while in the Western European countries and CEEC, it was from direct payments.

The cattle return, among different components of NMR (Figure 6), comprised the greatest part (26\% to $100 \%)$ of the NMR. The highest cattle return was observed in Nigeria's 50 cow-farm (28.8 US- $\$ 100 \mathrm{~kg}$ ECM) while the lowest was observed in PK-5 (1.3 US$\$ / 100 \mathrm{~kg} \mathrm{ECM})$ and IN-2W (1.3 US-\$/100 kg ECM). This may be explained by the fact that beef-oriented and dual purpose farms e.g. Africa and Asian farms, showed a relatively lower milk yield. Farms with lower milk yield have higher NMR, since these returns are expressed per $100 \mathrm{~kg}$ of milk. Same is true for the farms having higher beef returns due to higher beef prices (Africa, $\mathrm{NO}, \mathrm{CH}$, and BR-SE and BR-S). The cases of India and Pakistan revealed totally different results. In India, for religious reasons, the cow is treated as a "holy-mother" and cow slaughter is banned. On the other hand, the case for PK-5 could be due to a lower milk yield and a very low culling rate. The beef and heifer markets affected cattle returns as was evident in Bangladesh (BD-2), Indonesia (ID-3NG) and Iran (IR-90). The case was different in Africa, where the higher cattle return revealed that farms were mostly beef-oriented and of a dual nature, with a substantially lower milk yield (TN, EG, NG, and DZ).

\section{ii) Costs of Milk Production Only}

The cost of milk production only from both averagesized and large-scale typical farms in 46 countries and52 regions is depicted in Figure 7 . Most of the typical farms $(>50 \%)$ presented a cost between $25-45$ US-\$1100 kg ECM. The world's highest cost of milk production was found in Switzerland's 23 cow farm (97.27 US- $\$ / 100 \mathrm{~kg}$ ECM), followed by Canada's 58 cow farm (72.84 US-\$100 kg ECM) while the lowest was observed in Armenia's 15 cow farm (16.91 US$\$ / 100 \mathrm{~kg})$.

Due to these differences the standard deviation of the cost was relatively high (15 US- $\$ 100 \mathrm{~kg}$ ). However, in general, European countries including 


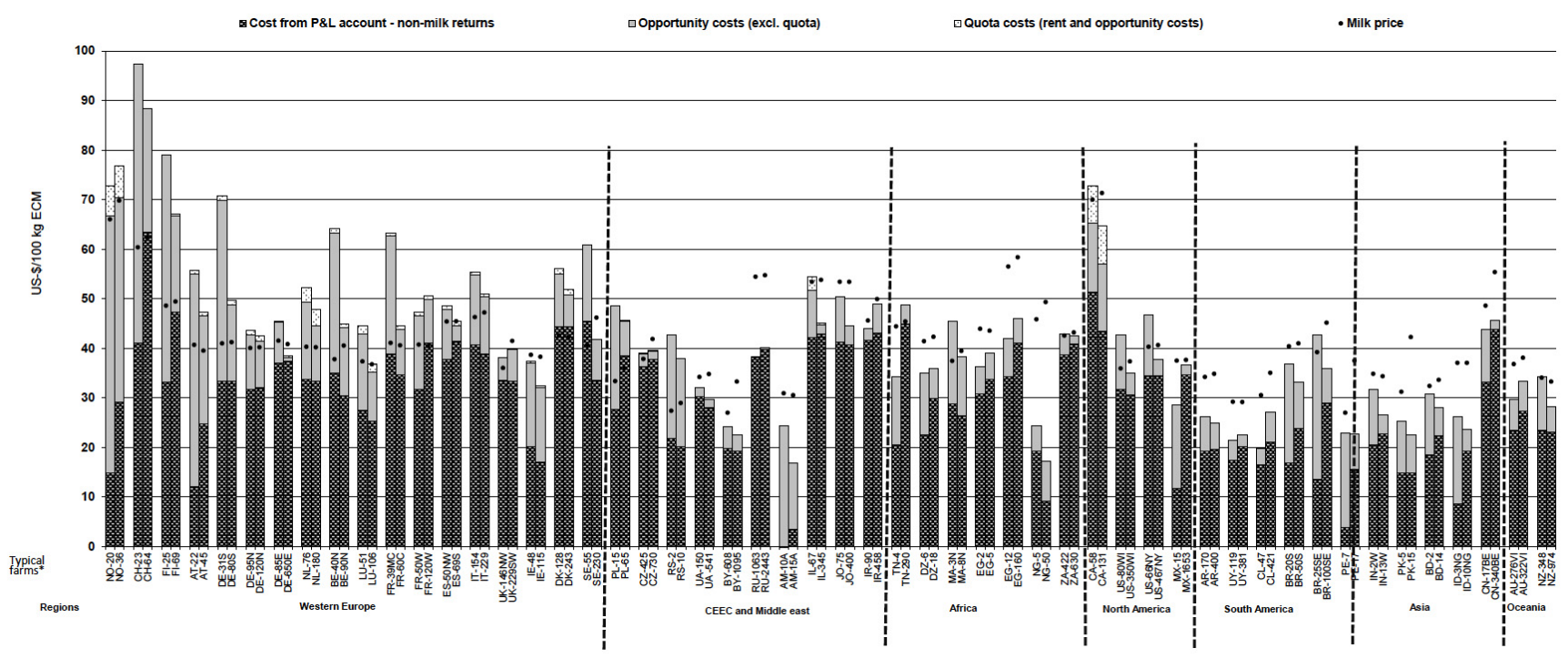

Figure 6: Cost of milk production (US- $\$ 100 \mathrm{~kg}$ ECM) in 46 countries.

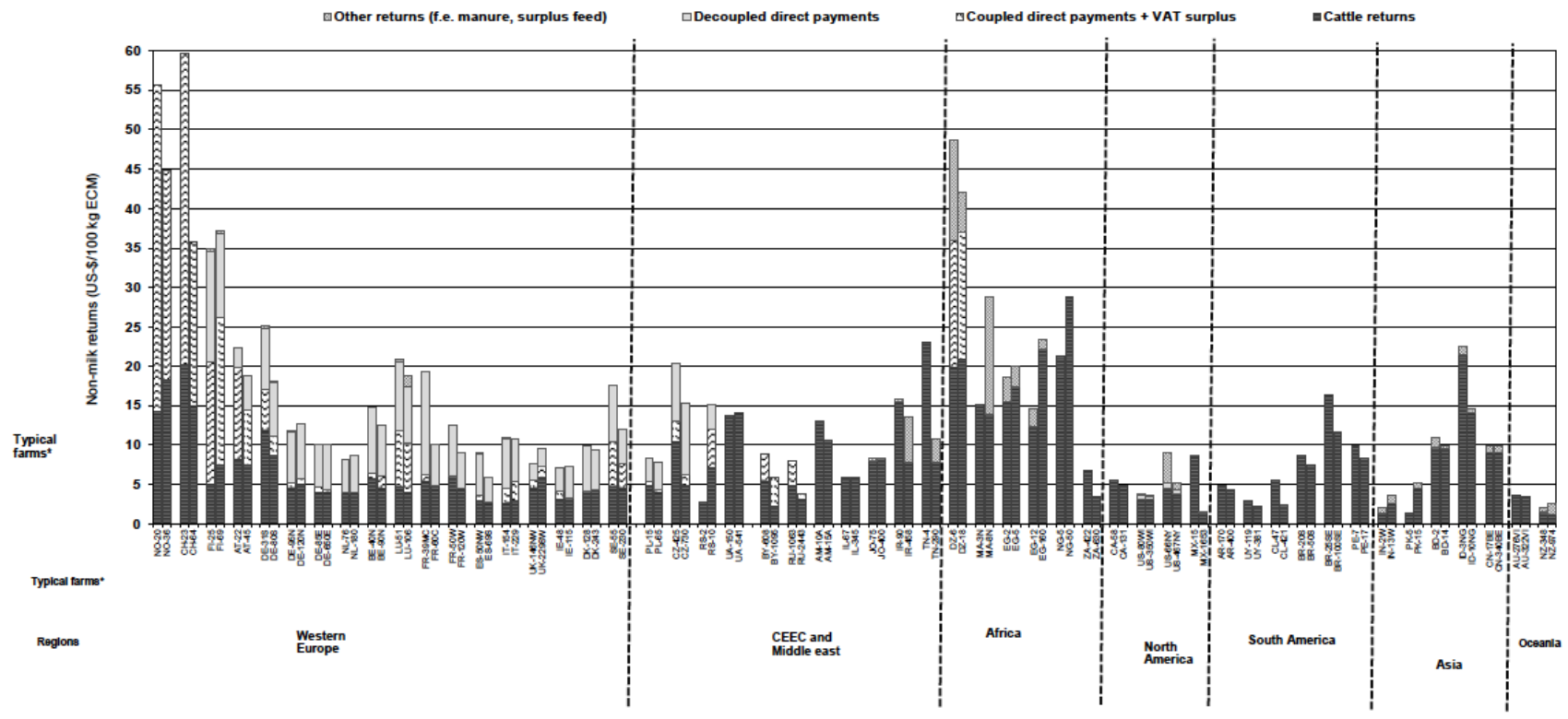

Figure 7: Non-milk returns (US-\$/100 kg ECM) in 46 countries.

Germany, France and Spain had a cost level between 40-50 US- $\$ 100 \mathrm{~kg}$ milk. Exceptions were Austria and Finland with higher costs, and the UK and Ireland with lower costs. The latter was partly due to the favorable climatic conditions for pasture growth, which allows dairy farmers to make better use of forage and reduce feed cost. Iran, Israel and Jordan from the Middle East also had a similar cost level of 40-50 US-\$ which was about 5 US-\$ higher than the costs in North Africa. The Middle East and North Africa are highly reliant on imported feed because they can only produce limited amounts of feed under their climatic conditions. The cost of milk production in the US and Brazil was about $35-40$ US- $\$ 100 \mathrm{~kg}$ ECM which is similar to the cost level in CEEC countries, including the Czech Republic,
Serbia, Russia and the household farms from Belarus.. The US costs were at these moderate levels mainly due to better feed management and efficiency leading to high milk yields. Excepting China and Brazil, the level of $<30$ US-\$ was common for South- and EastAsia (Bangladesh, India, Pakistan, Indonesia), South America (Argentina, Uruguay, and Chile) and Oceania (Australia and New Zealand). The farms in south and South East Asia, in addition to their low input systems are also dependent on crop residues mainly from their own farms for milk production, leading to lower production costs. On the other hand, farms in South America and Oceania are predominantly grazing systems which succeed to lower their cost of production by feeding more roughages and less of the 
expensive concentrates (Alqasi et al. 2011, Hemme et al. 2011, Hemme et al. 2012, Hemme et al. 2013, Hemme et al. 2014, Hagemann et al. 2012).

Cost of milk production is the main component of the dairy chain, and is therefore used as core indicator for benchmarking dairy farms worldwide. In this way, estimating costs of milk production can be used to understand the competitiveness of the dairy production in different regions. In addition, a comparison of the cost of milk production only and the milk price affords a good perspective of the profitability of the farms.

Based on this result, the cost of milk production only can be summarized to benchmark the cost in four main levels:

- Level 1 (benchmark 1): 40-50 US-\$ in the EU, Middle East and China

- $\quad$ Level 2 (benchmark 2): 35-40 US-\$ in the USA, Brazil, CEEC and Oceania

- $\quad$ Level 3 (benchmark 3): Level <30 US-\$ in Africa, Asia, South America

- Level 4 (benchmark 4): >60 US-\$ in Austria, Norway, Switzerland and Canada

\section{iii) Drivers of Cost of Milk Production/Factors Affecting Cost of Milk Production}

In order to be competitive in the global dairy market, it is necessary to invest in information on farming systems to be able to make strategic decisions on how to reduce the cost. Detailed input cost and the factors that influence the cost of milk production are indispensable tools with which to estimate the cost of milk production globally at farm level. To identify the drivers, a ranking method was applied to rank the individual cost items for inputs and factors of production based on their average value. In contrast, a regression analysis between the cost of milk production and several output parameters was made to understand the relationship and its importance in farm management decisions.

Details of the cost drivers are depicted in Table 3. The top three drivers for cost of milk production were: feed cost (18.15 US $\$ / 100 \mathrm{~kg} E C M)$, labor cost (11.98 US $\$ / 100 \mathrm{~kg} E C M)$ and machinery cost (3.10 US $\$ / 100$ $\mathrm{kg}$ ECM). This implies that the feed cost presented the highest share (with an average of $44 \%$ ) of the total cost in all the typical farms analyzed in this study, with a certain magnitude of variation. About $62 \%$ of the farms analyzed showed that the feed cost was $50 \%$ of the total cost of milk production. The feed costs were highly

Table 3: Different Individual Input Costs to the Cost of Milk Production Only (US-\$/100 kg ECM)

\begin{tabular}{|c|c|c|c|}
\hline \multicolumn{3}{|c|}{ World Average Cost of Milk Production Only ( $n=104): 42$ US/100 kg ECM (from Figure 1) } & \multirow[b]{2}{*}{$\mathbf{R}^{2}$} \\
\hline Rank & Individual Components of Cost of Milk Production Only & Ave. Costs $(n=104)$ & \\
\hline 1 & Feed (purchased feed, fertilizer, seed, pesticides etc.) & 18.15 & 0.03 \\
\hline 2 & Total labour costs & 11.98 & 0.18 \\
\hline 3 & Machinery (maintenance, depreciation, contractor) & 4.81 & 0.34 \\
\hline 4 & Total land costs & 3.29 & 0.02 \\
\hline 5 & Total capital costs & 3.1 & 0.28 \\
\hline 6 & Buildings (maintenance, depreciation) & 2.52 & 0.17 \\
\hline 7 & Fuel, energy, lubricants, water & 2.41 & 0.13 \\
\hline 8 & Veterinary and medicine and insemination & 2.09 & 0.26 \\
\hline 9 & Other inputs (dairy enterprise) & 1.64 & n. $a^{* \star *}$ \\
\hline 10 & Other inputs (whole farm enterprise) & 1.26 & n.a \\
\hline 11 & Insurance taxes & 0.91 & n.a \\
\hline 12 & Animal Purchases & 0.81 & n.a \\
\hline 13 & VAT Balance (if negative) & 0.11 & n.a \\
\hline
\end{tabular}

*Other inputs dairy enterprise: Milk supplies, herd testing, fees for pedigree records, bedding, fees for disease prevention board, hauling, promotion, milk quotano used

${ }^{* *}$ Other inputs: Fees for accounting and book keeping, advisory costs, phone \& utilities

${ }^{* * *}$ n.a $=$ not applicable. 
driven by the purchased feed costs as was observed in the farms which depend mostly on purchased feeds such as Jordan, Israel, Egypt and China. The high share of feed cost over the total cost agreed with the study performed by Alqaisi et al. (2011) and Hemme et al. (2012), who found that feed cost was more than $50 \%$ of the total cost. On the other hand, feed cost is also directly linked to the grain price, especially Soybean and Maize. The recent increase of the grain price, as a general tendency of other food commodities, as well as a greater use of grain for biofuel or ethanol and biogas production, is a matter of concern for dairy farmers. In order to stay in business, they need to find strategies for reducing feed cost. The high variation of feed costs over total costs (example, Iran, Jordan, China, and Uruguay), as observed in Figure 6 , shows the potential source for reducing feed cost. Increasing feed efficiency is one of the promising ways to reduce cost and increase profitability (Hutjens 2005, Hemme et al. 2014). The level of feed cost is also influenced by the level of milk production, feeding systems, land availability and prices (Hemme et al. 2014).

The second biggest cost driver was labor cost (both hired and family). Labor cost was higher than 10 US$\$ / 100 \mathrm{~kg} \mathrm{ECM}$ in approximately $47 \%$ of the farms analyzed in this study. The machinery cost was the cost driver, principally in developed countries and in specialized dairy producing regions. This was mainly observed in Western Europe and North America due to substantial investments in machinery.

In addition to the descriptive statistics from ranking, regression analysis was applied on i) variables related to farm economy of scale (farm size and milk yield), ii) variables that reflect the farm profit (entrepreneur's profit and milk price), and iii) input costs (feed costs). From an econometric point of view, it is not customary to regress farms which are very diverse in terms of farm input and outputs (as is demonstrated with a lower R2 (Figures $\mathbf{8 a}, \mathbf{8 b}$ and $\mathbf{8 c}$ ). However, it should be stressed that doing so provides substantial insights of the costs, specially revealing which are the most important factors that influence the level of cost in different farming systems worldwide. Three key variables were extracted from the regression analysis: farm size, milk yield and milk price. Although there was a strong correlation between cost of milk production and feed cost, it was not possible to avoid collinearity problems, as feed costs were already included in the cost of milk production (hence, it was not shown).
The regression results on cost of milk production and farm size were not able to confirm our hypothesis, that increasing herd size is associated with decreasing costs per unit of milk production. A farm size of 1600 cows is the optimum herd size (Figure 8a) where the marginal cost coincides with average cost, after which the cost increases. In general, most of the small-scale farms from developing countries e.g. Africa and Asia had a very small herd size with low costs. The main reason possibly was that these farms were operating on a low factor prices and low output basis, which was highly integrated with other agricultural activities such as crops and beef. The same hypothesis also holds true in the milk yield (Figure $\mathbf{8 b}$ ). Two exceptions were observed: a very high milk yield $(9369 \mathrm{~kg}$ ECM/cow/year) and low cost (27.09 US-\$100 kg ECM) for CL-421 and a high milk yield $(9800 \mathrm{~kg}$ ECM/cow/year) and high costs (60.81 US- $\$ / 100 \mathrm{~kg}$ ECM) for the SE-55 cow farm. The reasons for the first case (CL-421) were that the farm had very low labor, machinery and feed costs, as it was mainly grass based. On the other hand, SE-55 farm had very high wages for hired labor and opportunity costs for family labor. The high machinery and the quota cost also resulted in these high level costs.

It is interesting to note that the milk price, which is external to the farm and beyond its control, also affected the cost of milk production. A higher milk price was associated with higher costs (Figure $\mathbf{8 c}$ ) and this hypothesis held true until the milk price reached a level of 50 US- $\$ 100 \mathrm{~kg}$ ECM. The lower bound exception of this hypothesis was the NG-50 cow farm. This farm had very low costs but received a milk price of about 50 US- $\$ 100 \mathrm{~kg}$. The farm was situated in a suburban area and marketed its milk directly to the consumers. The other exception observed in this study was again the SE-55 cow farm which received a relatively low milk price but had very high milk costs. The CN-17BE farm operated with a marginal level of cost and milk price as this country had a cost of 43.86 US- $\$ 1100 \mathrm{~kg}$, which was slightly higher than the average cost of milk production among the countries analyzed in this study. The average milk price was approximately 48.86 US$\$ / 100 \mathrm{~kg}$. This price and cost coincided when a polynomial regression was made with $\mathrm{R}$-square of 0.332 . This implies that farms need to reduce the cost below that level in order to be profitable.

Based on the time series results (data not shown), it can be observed that before 2007, feed prices were low and there was no relation between cost and yield. The best fitting regression between cost of milk 


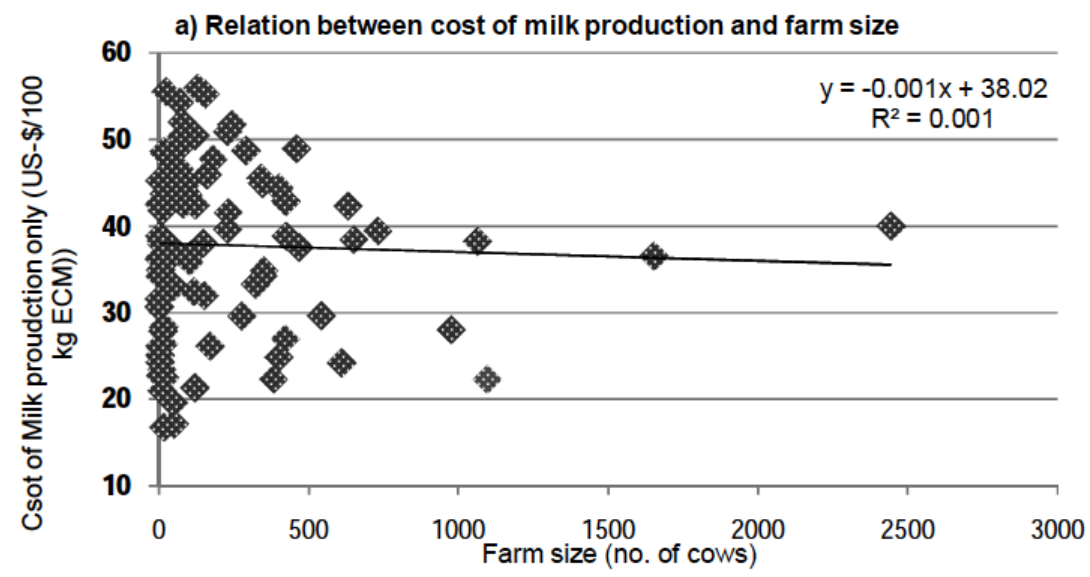

(b) Relation between cost of milk production only and milk yield

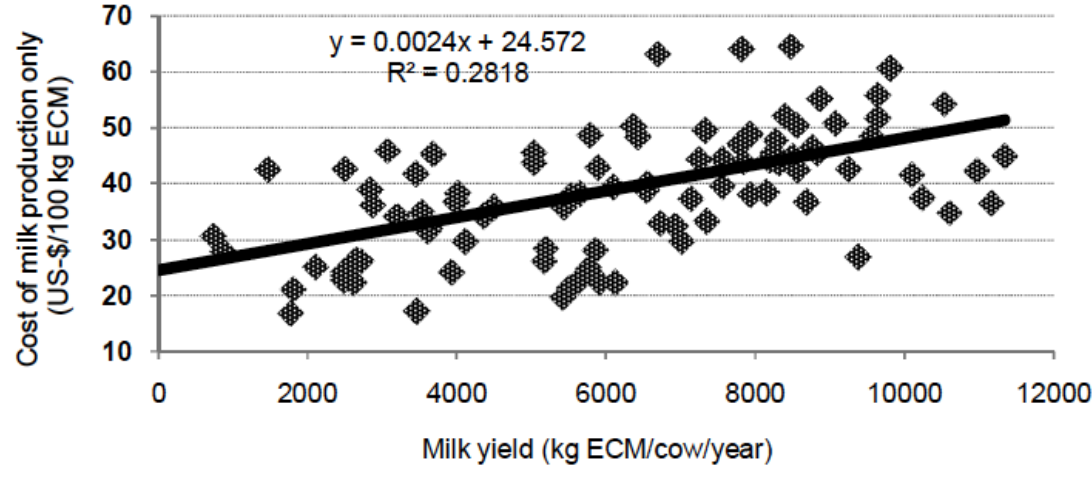

(c) Relation between cost of milk production only and milk price

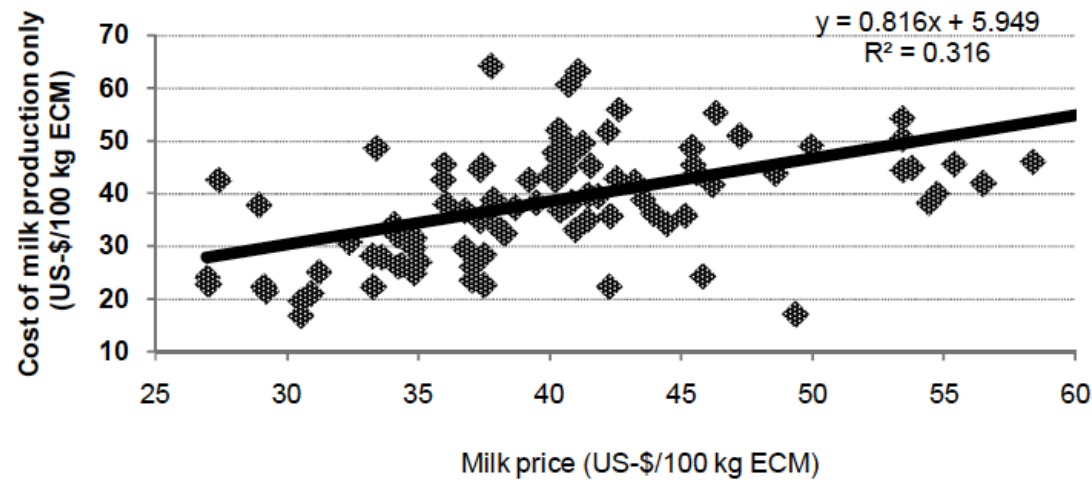

Figure 8: Relation between cost of milk production and herd size (a), milk yield (b) and milk price (c).

production and milk yield was observed in $2009\left(R^{2}=\right.$ 0.43 ) indicating that an increase of $1000 \mathrm{~kg}$ milk was associated with the increase of about 3.6 US- $\$ 100 \mathrm{~kg}$. From 2009, the slope and $R^{2}$ declined, mainly due to a very high feed price and increase in salaries in low yield farm types and emerging countries.

\section{iv) Implications for Strategic Farm Decisions}

The farm level milk production cost can be grounded on two key reasons: i) the highest share of cost is incurred at the farm along the global milk supply chain, ii) more than one billion people live either directly or indirectly on dairy farms worldwide (IFCN 2012; Hagemann et al. 2012). Accordingly, the IFCN typical farm approach provides an opportunity to estimate the cost of milk production globally, which in turn makes it possible to benchmark the dairy farm based on cost of milk production.

This study provided key insights on specific input and factor costs. The feed costs had the greatest impact on the total cost. The recent leap in grain prices has made them rise over the 2008 level, which was reflected in this study as the mean proportion of feed cost to the total costwas observed as $55 \%$ with a 
standard deviation of $15 \%$. The existing higher feed cost was combined with the recent rise in feed cost from 10 to $15 \%$ in 2011 compared to 2010 . In the same way the high cost of labor, combined with the other two factors of production (land and capital), was heavily driven by the country specific factor, market policy and factor endowments. For example, the high labor costs in Switzerland reflected the general economic policy on labor wages, while the lack of labor in dairy farming (e.g. India) reflected the future perspectives of dairy farming in certain countries. The wages of labor increased rapidly in Eastern Europe, some emerging countries and BRIC countries (Brazil, Russia, India and China).

Finally, producing milk at a competitive cost is the overall goal of a sustainable dairy production system. In an era of an increasing feed price and a fluctuating milk price, the global dairy industry is becoming more and more competitive while farmers face difficulties to adjust their production system to keep a competitive position. This implies that it is necessary for farmers to understand the global, changing and dynamic input and output market. The results of this study have shown a number of important implications both for dairy farming and for the global dairy industry.

1) The estimation of cost using the specific comparable method applied in this study, has provided a great opportunity for typical farmers to observe their own cost and benchmark it with the cost of other farms internationally.

2) The detailed analysis and ranking of the cost items to the total cost of milk production demonstrated which input cost was the highest contributor to the total costs of milk production. This information will help farmers make strategic decisions on how to handle costs and develop a cost reduction strategy.

3) Once the different cost contributors are known, it will be easier to prioritize the allocation of resources within the farm. A farmer could, for example, decide whether to produce feed on his farm or to purchase it, based on wages for labor, rent price for land and market price for feed. In most transition and developing countries, wages for labor have increased significantly over the years. Based on their knowledge of the cost contribution, farmers could decide if (and when) they should intensify production through mechanization or continue with labor intensive systems.
4) The cost of milk production at the farm level objectively supports the other stakeholders of the global supply chain. For example, milk processors may use it to base their decisions when develops their processing plants. However, although this paper provides the facts on costs so that processors and other policy makers may obtain an overview, the decision whether to apply it in their business strategy or not, should depend on their own policy framework and the way their business is run.

\section{CONCLUSION}

This study compared milk production costs in 104 typical farms from 46 countries and 52 dairy regions by applying a harmonized method developed by IFCN. Each farm represents a particular farm types and regions per country. The average cost of milk production in all analyzed farms was 42 US- $\$ 1100 \mathrm{~kg}$ ECM with a range from 16.9 to $97.3 U S-\$ / 100 \mathrm{~kg}$. The highest costs were observed in Western Europe (53.6 US $\$ 1100 \mathrm{~kg} E C M)$ due to higher input costs. In contrast, the lowest cost (30.41 US $\$ / 100 \mathrm{~kg}$ ECM) was observed in Asia.

Moreover, the ranking of individual cost items showed that feed cost (defined as sum of purchased feed and home grown feed costs) was the highest cost contributor followed by labor cost. Although a hypothesis had been considered, that the levels of milk yield and herd size were highly correlated with the cost of milk production, a strong relationship between them was not observed in this study. Furthermore, the regression analysis revealed that farm size had a low impact on cost reduction while both milk yield and milk price had a moderate impact. In the short term, farmers can cope with lower milk price and higher cost but in the medium and long-term term, the production costs should always be lower than the returns, independently from the milk price level. This implies that when the milk price is low, farmers might need to adjust their management strategies and farming system otherwise they will go out of business and compel to exit from dairying.

This study attempted to extrapolate the results from selected typical farms to represent particular milk volumes in a region or country. The representativeness of these farms may be a challenge especially if the selection of typical farms does not strictly follow the TFA. However, the IFCN method, since it was first applied in 2000, has been continuously refined and 
developed in order to be applicable at an international level. The outcome of this study clearly showed that the IFCN method is highly suitable for comparing farms on a global scale based on cost, with limited resources, time and diverse farming systems. Based on the results of this study, it may be concluded that feed costs, labor costs, opportunity costs for factors of production and quota costs are highly relevant when considering strategies to reduce the cost. It is also necessary to consider the evolution of cost of milk production with particular emphasis on the historic development of input and output costs and prices. However, these were beyond the scope of our study, hence further studies may be required to address time series analysis on these factors.

Annex 1A: Background information on the typical farms analyzed in this study

Annex 1B: Background information on the typical farms analyzed in this study

\section{REFERENCES}

Alqaisi, O., Ndambi O.A. and Hemme T. 2011. Global view on feed cost and feed efficiency on dairy farms. AllAboutFeed.net, 2(4): $\quad 2011$, http://www.allaboutfeed.net/ProcessManagement/Management/2011/7/Global-view-on-feed-costand-feed-efficiency-on-dairy-farms-AAF011993W/

Alvarez, A., del Corral, J., Solis, D., Perez, J.A., 2008. Does Intensification Improve the Economic Efficiency of Dairy Farms? J. Dairy Sci. 91, 3693-3698. http://dx.doi.org/10.3168/jds.2008-1123

Barker, D., Hallberg, M.C., Tanjuakio, R., Eletrich, J., Beck, R.L. and Liebrand, C.B.1990. Estimates of costs of producing milk in seven major milk producing countries 1986. USDA, ERS, Washington.

Brag, L.A. and T. J. Dalton. 2004. Factors Affecting the Decision to Exit Dairy Farming: A Two-Stage Regression Analysis. J. Dairy Sci. 87: 3092-3098. http://dx.doi.org/10.3168/jds.S0022-0302(04)73444-X

Breustedt, G. and T. Glauben.2007. Driving forces behind exiting from farming in Western Europe. J. Agri. Econ.58(1): 115127 http://dx.doi.org/10.1111/j.1477-9552.2007.00082.x

Brierley, Cowton, Drury.2001. How production costs are calculated and used in decision making: a pilot study, Managerial Auditing Journal 16/4, 2001, MCB University Press, pp. 202206

Butault, J.-P., Moreau, R., Roussellle, J.-M. 1995. La vaiabilite des couts de production dans six pays del'Europe du nord: Allemagne, France, Pays-Bas, Danemark, Royaume-Uni et Irlande. Cahiers de L'onilait, 14, 48-60.

Custer, R. L., Scarcella, J. A., Stewart, B. R., 1999. The modified Delphi Technique - A rotational modification. Journal of vocational and technical education 15(2)

Deblitz, C. 1993. International Vergleich von Systemen extensiver zielgebundener Gründlandnutzung-produktionstechnische und ökonomische analyze der Wettbewerbsfähigkeit, internationale Übertagbarkeit. Mellen University Press, New York.
FACEPA (Farm Accountancy Cost Estimation and Policy Analysis of European Agriculture). 2008. Cost of production: Definition and Concept, FACEPA Deliverable D1.1. 2 - October 2008, INEA - Italy. Available at: http://www.rica.inea.it/public/it/ view_file.php?action=article\&id=127\&ext=pdf\&data_type=ap plication/pdf. accessed at April 2012.

Fingleton, W. A.1995. Comparative costs and returns for milk production in European countries. Annual conference of the Agricultural Society of Ireland, Dublin.

French, B. 1992. The analysis of productive efficiency in agricultural marketing: models, methods and progress, in a survey of Agricultural Economics Literature volume I, Traditional Fields of Agricultural economics, 1940s to 1970s, Ed. Lee R. Martin, 1992.

Gonzales-Gomez, J.I. and Morini, S.2009.A model for cost calculation and management in a multiproduct agricultural framework. The case for ornamental plants. Spanish Journal of Agricultural Research 2009 7(1), 12-23. http://dx.doi.org/10.5424/sjar/2009071-394

Hagemann, M., Hemme, T., Ndambi, O.A., Alqaisi, O. and Sultana, M.N. 2011.Bechmarking of greenhouse gas emission of bovine milk production systems for 38 countries. Animal Feed Science and Technology. vol. 166, pages 46-58. http://dx.doi.org/10.1016/j.anifeedsci.2011.04.002

Hagemann, M., Ndambi, A., Hemme, T. and Latacz-Lohmann, U. 2012.Contribution of milk production to global greenhouse gas emission: an estimation based on typical farms. Environ SciPollut Res Int http://dx.doi.org/10.1007/s11356-011-0571-8

Hemme, T., O.A. Alqaisi, O.A. Ndambi, and D. Boelling. 2014. IFCN contribution to the IDF/FAO/IFCN joint project, World Mapping of Animal Feeding Systems in the Dairy Sector. International Dairy Federation (In press).

Hemme, et al., 2011. IFCN Dairy Report 2011.International Farm Comparison Network, IFCN Dairy Research Center, Kiel, Germany.

Hemme, et al., 2012. IFCN Dairy Report 2012.International Farm Comparison Network, IFCN Dairy Research Center, Kiel, Germany.

Hemme, et al., 2013. IFCN Dairy Report 2013.International Farm Comparison Network, IFCN Dairy Research Center, Kiel, Germany.

Hemme, T., 2000. Ein Konzept zur international vergleichenden Analyze von-Politik-und Technikfolgen in der Landwirstschaft. Land bauforschung Völkernode, Sonderheft, 215 (2000).

Hemme, T., Garcia, O., Khan, A. R., 2004. A Review of Milk Production in Bangladesh with particular Emphasis on smallscale producers. FAO-Pro-Poor Livestock Policy Initiatives working paper No. 7. http://www.fao.org/ag/againfo/ programmes/en/pplpi/docarc/execsumm_wp07.pdf

Holzner, J., 2004. Eine Analyze der Internationalen Wetwewerbsfähigkeit der Milcherzeugung an ausgewäahlten Standorten in Ostdeutschland, der Tschechischen Republik und Estland. Landbauforschung VölkennordeForshungsanstalt für Landwirtschaft Braunschweig 282.

Hutjens, M.F., 2005. Dairy efficiencyand dry matter intake. Proceedings of the 7th Western Dairy Management Conference March 9-11, 2005- Reno, NV- 71, available at: http://www.wdmc.org/2005/8Hutjens.pdf, accessed date: December 2012

International Farm Comparison Network (IFCN), 2012. IFCN Dairy Report 2012, Schauenburger Str. 116, 24116 Kiel, Germany. www.ifcndair.org

Isermeyer, F. 1989. Die Wettberbsstellung der deutschen Landwirtschaft in der Milchproducktion, Göttingen.

Isermeyer, F., 1998. Produktionsstrukturen, Produktionskosten und Wettbewerbesstellung der Milchproduktion in Nordamerika Neuseeland und der EG. Wissenschaftsverlag Vauk, Kiel. 
Isermeyer, F., Hemme, T. and Holzner, J. 2003.Analysis of international competitiveness of milk production in the framework of the IFCN. Agricultural Economics-Czech 49(2):94-100.

Isermeyer, 2012. Production cost calculations and methodologies used for Dairy, Beef, Pork and Poultry Industries. In: Langrell, S, Ciaian, P and Paloma, S, G. Y (Editors). Production Costs in the Global Farming Sector: Comparative Analysis and Methodologies. JRC Scientific and policy report-EUR 25436 EN.

Knutson, R.D., Roman, R., Anderson, D.P., Richardson, J.W. 1997. Farm Level consequences of Canadian and US Dairy policies. AFPC working paper 97-8; Agricultural and Food Policy Center, Department of Agricultural Economics, Texas Agricultural Experiment Station, Texas Agricultural Extension Service, Texas A\&M University.

Koonawootrittriron, S., Elz, M. A., Yeamkong, S. and Suwanasopee, T. 2012. A comparative study on dairy production and revenue of the dairy farms supported by a dairy cooperative with those supported by a private organization in Central Thailand. Livestock Research for Rural Development. Volume 24, Article \#61. Retrieved May 1, 2012, from http://www.Irrd.org/lrrd24/4/koon24061.htm

Miller, J.W. 1997. Assessing the Farm-Level Competitiveness of milk production in Mexico and the United States.Dissertation, Texas A\&M University, Texas.

Ndambi, O. A., Garcia, O., Balikowa, D., Kiconco, D., Hemme, T., Latacz-Lohmann, U., 2008. Milk production systems in Central Uganda: a farm economic analysis. Tropical Animal Health and Production 40, 269-279. http://dx.doi.org/10.1007/s11250-007-9091-4
Ndambi, O. A., Hemme, T., 2009. An economic comparison of typical dairy farming systems in South Africa, Morocco, Uganda and Cameroon. Tropical Animal Health and Production 41, 979994.

http://dx.doi.org/10.1007/s11250-008-9288-1

Richardson, J.W. 1998. Simulation: A tool for decision making. Department of Agricultural Economics, Texas A\&M University, Education paper for simulation class.

Thorne, F.S., 2004. Measuring the competitiveness of Irish Agriculture (1996-2000). The rural economy research center working paper series, Working paper 04-WP-RE-02. http://www.teagasc.ie/research/reports/ruraldevelopment/506 5/eopr-5065.pdf

Uddin, M. M., Sultana, M. N., Ndambi, O. A., Hemme, T., Peters, K. J., 2010. A farm economic analysis in different dairy production systems in Bangladesh. Livestock Research for Rural Development. Volume 22, Article \# 122. Available at: http://www.Irrd.org/Irrd22/7/uddi22122.htm

Uddin, M.M., Sultana, M.N., Brümmer, B and Peters, K.J. 2012. Assessing the impact of dairy policies on farm-level profits in dairy farms in Bangladesh: Benchmarking for rural livelihoods improvement policy. Journal of Reviews on Global Economics, 1, 124-138.

vanCalker, K.J., Berentsen, P.B.M., Giesen, G.W.J., Huirne, R.B.M., 2005. Identifying and ranking attributes that determine sustainability in Dutch dairy farming. Agriculture and Human Values 22, 53-63. http://dx.doi.org/10.1007/s10460-004-7230-3

(C) 2014 Hemme et al.; Licensee Lifescience Global.

This is an open access article licensed under the terms of the Creative Commons Attribution Non-Commercial License (http://creativecommons.org/licenses/by-nc/3.0/) which permits unrestricted, non-commercial use, distribution and reproduction in any medium, provided the work is properly cited. 